\title{
居間の変化と客間・寝室の配置からみた二階建て住宅の理念形成
}

\section{- 明治後期〜昭和初期刊行の住宅関係単行本の言説にみる近代都市独立住宅の二階建てに関する研究一 \\ THE IDEA OF 2 STORY HOUSE FROM THE VIEW POINT OF CHANGE OF ROOMS FUNCTION AND ARRANGEMENT}

- The study on 2 story urban modern houses with discourse analysis of housing books published in prewar Japan -

\author{
㴊上 貴由樹*, 内田 青蔵** \\ Takayuki FUCHIKAMI and Seizo UCHIDA
}

\begin{abstract}
This paper clarified the idea of 2 story Japanese urban houses with the discourses analysis 63 housing books published from the late Meiji to early Showa periods. We confirmed that the function of Japanese traditional housing room the "Ima" changed from private room into public room (as a western living room) during the Taisho periods, accordingly the discourses of drawing rooms arranged on 2nd floor were centralized in middle of Taisho period, the discourses of bedrooms were appeared from the late Taisho to early Showa period. We considerd that the function differentiation of the Ima lead to formed the 2 story houses idea.
\end{abstract}

keywords: 2 story houses, Modern housing, Housing books, Living room, Drawing room, Bedroom 二階建て住宅, 住宅近代化, 住宅関係単行本, 居間, 客間, 寝室

\section{1. はじめに}

日本の住まいにおける二階建ては、江戸期の町家や長屋などで確 認できるが、一階と同じように二階を居室 ${ }^{1)}$ に充てることは上流階 層の屋敷や別邸など一部に限られていた ${ }^{2)}$ 。そうした意味で一般的な 住まいに二階が広く浸透し始めたのは明治期以降といわれており ${ }^{3)}$ 、 二階化の要因のひとつとして「間取りの機能分化が進み、複数の部 屋が必要になったこと」 ${ }^{4)}$ があげられる。本稿はこの観点から、とり わけ当時の「居間」 ${ }^{5)}$ (以後「居間」の「」を略す。）の変化につい て着目する。居間は従来、私室の機能を主として夜は就寝の場であり、 客の応対にも利用されるなど多様な機能を包含していたが、大正期 以降にいわゆる「家族本位」の住居観が形成されるに伴い、「家族団 らん」の場や、欧米的な「リビングルーム」へのイメージ転換が積 極的に試みられた。もちろん他の居室にも変化は見られ、互いに影 響し合ったことも考慮すべき ${ }^{6)}$ ではあるが、居間は住宅の近代化の なかで間取りの機能分化に最も大きな影響をおよぼした居室である と考えられる。また当時の居間の変化については「建築家だけに通 用する概念」という限定的な展開 7) であったという解釈があるもの の、住宅の間取りを近代的な価値観に対応させようとする理念的な 動向を捉える意味ではむしろ重要であり、こうした動きのなかにこ そ二階建て住宅の間取りに対する先導的な考えが含まれているとも 考えられるのである。本稿は二階建て住宅の間取りの変化がどのよ うな背景をもとにして形成されたのかを、居間の変化に伴う「客間」 ${ }^{8)}$ 、 「寝室」9)の居室の二階配置の動向から検討寸るものである (以後「客

* 佐賀大学大学院工学系研究科 助教 $\cdot$ 工修 $($ 神奈川大学研究員)

** 神奈川大学工学部建築学科 教授・工博
間」「寝室」の「」を略す)。

これまでの近代住宅史における二階に着目した研究については、 明治期の二階の座敷の様子を分析したものに、東京・佃島の住居類 型の変遷をみた江面 ${ }^{10)}$ 、福岡・柳川の住宅における二階座敷の造り の変化を考察した百田ら ${ }^{11}$ 、大阪・池田新市街（室町）の分譲住宅 の平面形態について分析した吉田 ${ }^{12)}$ の研究があげられる。前二者は 町家の形式を含みつつも建設年が下がるにつれて二階が床の間付き の座敷として利用されていく発展的な様子について、後者は明治末 期の最も早い時期に計画された郊外住宅地の二階建て住宅平面に注 目し、二階が客座敷に充てられていた実態に言及している。以上の ような実例を扱った研究のほかに戦前期の都市住宅提案の二階居室 用途の変化に着目し、住宅平面における階段の位置関係から検討し た古俣ら ${ }^{13)}$ 、図案の数量分析から検討した立川ら ${ }^{14)}$ の研究があげら れる。両者とも当時の建築家の著した住宅関連書籍に掲載されてい る住宅図案を分析したものであり、提案的な内容を含む理念的動向 として限定されるが、いずれも大正期後半頃から接客から家族用寝 室への二階居室用途の変化について指摘している。

ところで近代における住宅平面の変遷に関する研究については、 木村の研究 ${ }^{15)}$ を嚆矢として、その後幾多の検討 ${ }^{16)}$ が重衫られ、中廊 下形住宅平面、居間中心形住宅平面をはじめとする近代的な住宅平 面形式の成立過程が明らかにされているが、そうした検討の中にも 当時の二階平面に対する提案の様子について触れられている。宮崎 らは大正期における家族本位計画論の成立過程に一階南面する最も

Assist. Prof., Graduate School of Science and Engineering, Saga Univ., M. Eng. (Researcher of Kanagawa Univ.)

Prof., Dept. of Architecture, Kanagawa Univ., Dr. Eng. 
良い場所を居間に譲り、客間は二階に配置するという「2 階座敷 説」 ${ }^{17)}$ が存在したことについて、また青木 ${ }^{18)}$ は生活改善同盟会の 「住宅間取り及設備の改善」を参照し、公私を明瞭に区別するには 二階建てとし寝室を二階に設けることが推奨されたことに言及する など、居間の変化から住宅平面の二階化を想記させる興味深い指摘 がなされている。しかし、これらはあくまで主階である一階平面に おける居間の配置を主体に論じる過程で指摘されたもの ${ }^{19)}$ であり、 二階建て住宅の変化の様子については断片的である。

以上の既往の成果を整理すると、大正期において二階の家族寝室 化の兆しが窥われ、それは今日定着している二階の寝室利用の考え 方に通ずる可能性が考えられるものの、一・二階双方の動きを含め た二階建て住宅としての平面構成の変遷については具体的に明らか にされてはいない。

筆者はこれまで、近代における二階建て住宅平面の変遷に関寸る 研究を行ってきており ${ }^{20)}$ 、二階建て住宅に対寸る理念形成とそれ に伴う平面構成の変遷過程を明らかにすることを目指している。そ して、この二階建て住宅の理念形成を分析するための資料として当 時の建築家ら ${ }^{21)}$ が著した単行本を主史料として着目してきた。住 宅に対する計画的な考え、とりわけ居間、客間、寝室の 3 室の対応 関係を単行本ごとに抽出でき、その通時的な変化の様子を丁寧に見 ることができると判断したためである。

以上のように、本稿は戦前期の単行本を主史料として接客から家 族寝室への二階居室用途の変化が指摘されている大正期を中心にそ の前後を含めた期間である明治後期から昭和初期までを対象期間と し、建築家らの言説から一階居間の変化に伴う客間および寝室の二 階配置の動向とその背景について分析することで、近代都市独立住 宅の二階建てに対する理念形成を明らかにすることを目的とする。

\section{2. 研究史料について}

本稿は、「二階」「二階建て」の計画を導く条件や考えを多分に抽 出できる資料 ${ }^{22)}$ として住宅関係の単行本 (以降、住宅関係単行本 と略す）を用いる。住宅平面の重層化は何らかの条件や意図が働く ことで検討される場合もあり、住宅平面理論に関する言説に必ず記 述されるとは限らない。従ってなるべく多くの情報のなかからどの 時期に二階を扱う言説が集中するのかを明らかにする必要がある。 住宅関係単行本は明治期半ば頃から新しい社会階層として台頭し た俸給生活者を中心とする都市中流層 ${ }^{23)}$ を主たる読者層としたも のであり、明治後期以降に刊行数は急増した ${ }^{24)}$ 。通俗的に書かれ、 住宅手引き書としての性格 ${ }^{25)}$ をも書籍が多く含まれ、世間一般 に対する住宅改良の啓蒙書としての役割を担ったとみることができ る。したがってこれらには住宅建築に対する基本原則である各部屋 の機能と間取り方法が丁寧に解説されているものが多く、間取りに 対する考えの変化を居室ごとに細かく読み取るうえで最適な史料で あると判断した。

住宅関係単行本の選出方法として、国立国会図書館所蔵図書 ${ }^{26)}$ から日本十進分類法の「建築学」 ${ }^{27)} 、 「$ 住宅建築」 ${ }^{28)}$ に該当する明 治期から昭和初期 (戦前期) までに刊行された単行本を対象とし、 そのうち、住宅居室の配置方法に関する言説が含まれている記述を 分析対象として扱うこととした。なお、雛形本、研究書、海外・先 駆的事例の掲載を中心とした専門的内容に特化した書籍、また独立
住宅以外の貸家、長屋、店舗兼住宅など専用住宅以外に焦点をあて ている書籍については、当時の都市独立住宅における二階居室配置 の動向をみる上でやや異なる方向を示寸可能性が考えられるため対 象から除外した。以上の選出方法に該当した書籍、計 63 冊を住宅 関係単行本として分析対象とする (表 $1_{-}$左欄部分)。

\section{3. 居間の機能・配置方法の変化に伴う客間と寝室の二階配置動向}

居間の機能・配置方法の変化に伴う客間および寝室の二階配置の 動向をそれぞれの対応関係として見るために、3 室の居室配置を見 るうえで重要と思われる項目を挙げ、文献ごとのその記述有無につ いて整理した（表 1 _居間、客間、寝室欄）。ここでは各項目の言 説について現れる時期および期間を 3 室の影響関係から整理するこ とにし、二階配置の言説については次章で分析する。なお居室ごと にみられる変化を追ううえで、他の項目の動向と比較する必要があ るため、各項目を $\mathrm{a} \sim \mathrm{r}$ の小文字英字で表記し、かつ各項目に該当 する記述が連続的に確認できる場合は、当該期間を小文字英字に数 字を付して表した（例：a1,b1, 以下同様に扱う)。

\section{1 居間の機能・配置方法の変化}

はじめに、居間の動向について検討した結果、居間の[機能］、[起 居様式）ならびに［配置方法］に関する言説を整理した（表 1 _居 間欄。［］は表 1 の項目名称を指寸。以下、同様に扱う)。居間には様々 な機能が含まれているが、客間および寝室の二階配置を間取りにお ける公私領域の確立の過程として捉えるならば、居間に対する公私 の捉え方の変化に着目できる。この観点から［私室］、[家事監督］、 [家族共用] の 3 つの機能をとりあげることができた ${ }^{29)}$ 。これらの 言説の動向をみると、最初の 1899 (明治 32) 年の『家屋改良談』(No. 1) に確認できたのは [私室］の機能である。その後の文献でも、「日 常起居する家族等の居間」 ${ }^{300}$ 、「主人、夫人居間」 ${ }^{31)}$ というように「家 族個々人の居間」の意図が含まれ、こうした記述は 1921 (大正 10) 年の文献まで継続的に確認できる（a1）。ところがこれ以降は急減 を示し、居間の解説に [私室］としての機能は含まれなくなる。続 いて [家事監督］の機能については、1915（大正 4) 年『理想の住 宅』(No.9) から 1928（昭和 3) 年の文献まで［私室］に付加される 形で継続的に確認できる（b1）。この［家事監督］は、「居間の位置 の選び方は其の家の主婦にとつて最も緊要で... (中略)、居間の選 び方が悪いと書生の取締は勿論萬事に不便なことが多い」 ${ }^{32)}$ とい うように、居間を主婦の家事行動の拠点とみな寸もので、先の「私 室」と比較するとやや公的な意味合いが含まれていると見られる。 そして [家族共用］の機能については、1919（大正 8）年『楽しき 住家』(No14)において最初に確認できる。「居間（リビングルーム） …中略、リビングルームは書間いつも居る室で、談話讀書等…」 ${ }^{33)}$ というように、居間を「リビングルーム」と称していることからも 欧米的な居間空間を参考にしていることが分かる。このような言説 は1921（大正 10）年以降増え、1923（大正 12）年から昭和期へと 継続してみられる (c1)。以上 3 つの項目ごとの継続期間の推移を 追うと、当初は［私室］の意味として居間の説明がされていたのが、 大正期に入るとそこに [家事監督 $]$ の機能が付加され、大正期の後 半頃を境に [私室 $]$ から [家族共用］一居間の機能が移行すること が分かる (a1, b1, c1)。

次に居間の [起居様式]の動向を見る。基本的には [床座 ${ }^{34)}$ の 
解説が対象期間中まんべんなく確認できる（d1）。これに対し［椅子 座]は1915（大正 4) 年の『理想の住宅』(No.9) において最初に確 認でき、その後しばらく出現頻度は少ないままであったが、1923（大 正 12）年『理想の文化住宅』（No. 25）から増加し、昭和期以降も継 続して確認できるようになる (e1)。

こうした動向を踏まえつつ居間の［配置方法］の動向と照らし合 わせながら見ていくと、まず、1899（明治 32）年『家屋改良談』(No. 1) に「(居間は) 寒冷ならしめざる事極めて必要なり之を南側に移せば 日當りよくして」 ${ }^{35)}$ と、最も早い文献で既に［南面配置］の言説が 確認できる。ところが明治期の他の文献では「日光の透射の可い、 静かな場所」36) のように、従来的な居間の [私室］の秘匿性一の配 慮から、明確に南面を推奨寸ることが記述に現れていない。つまり 明治末期までの文献には居間の [南面配置] は定説化されるには至っ ていないと見られる ${ }^{37)}$ 。(a $1, \mathrm{f}$ 列) ところが大正期に入ると様子に 変化が現れ、次のような [南面配置］を推奨する言説が連続して確 認できるようになる（f1）。

居間は毎日書夜とも使用寸る所であるから、便利多き階下を撰んで、夏は 涼しく冬期は暖かい所、即ち南向の日當りよくして風通し宜しき所に設け ねねばならぬ。従つて庭園も居間より眺めることになるのである。居間の位 置の選び方は、その家の主婦にとつて最も大切で、押入の附け方から、士蔵、 納戸との関係、廊下へ出る工合、臺所との関係、客室、玄關、女中部屋へ の連絡等を研究して、最も適當な場所を選びたい。居間の選び方が悪いと、 下婢や書生の取締は勿論、萬事に不便な事が多い。

(納屋松藏 編著『經濟本位の住宅』鈴木書店, T9.2（No. 15)）

このように、居間に対して [家事監督] の機能が加わり、[私室］の 役割が希薄になったことが作用して［南面配置］が明確に記述され るようになったと解釈できる。さらに1921 (大正 10)年を境にして、[住 宅の中央部]の言説が増える $(\mathrm{g} 1)$ 。そこでは以下のような言説も現れ、 居間の公室化により間取りにおける重要度が増すようになる。

居間は家庭全體の中心となるのですから、其の位置は家屋の中央に位し、 … (中略)、必要な家具は中央に居間卓子と椅子とそれによい氣持の肘掛椅 子に寝椅子を取り混ぜて…(中略)、生活改良の立場からいっても住宅は家 族本位にしなければならないと思ひます。(…(中略) は筆者による。以下 同様に用いる)

(文化研究会 編『文化住宅の研究』文化研究會, T12.4 (No. 26))

このように、居間を「家庭全體の中心」とみなし住宅平面の中央部 分に配置することを標榜しつつ、[椅子座］を基本とした家具の解説 が付されるなど、洋室化した家族共用の居間、寸なわち「リビングルー ム」の居間空間 ${ }^{38)}$ が想記される。こうした傾向が強まることは [椅 子座］および［住宅の中央部］が同時期の 1921（大正 10）年以降か ら継続的に見られることからも確認できる（e1, g1)。

以上のように大正期を中心に、居間機能の公室化から間取りにお ける重要度を増していく様子が窥える。これは当時の建築家らによ る居間に対する概念変化の過程 ${ }^{39)}$ に他ならず、住宅関係単行本の言 説を刊行年順に通観した場合でもこうした動向の現れを読み取るこ とができる。

\section{2 客間の二階配置に関する動向}

客間に関寸る言説から、その配置方法について項目ごとに分けて 整理した結果、大きく［二階配置］［兼用］［その他］に分けること ができる(表 1 _客間配置欄)。まず明治後期〜大正期初頭の文献では、 部屋の方位に注意が払われている様子が窥えるが、南面もあればそ の逆の北面を主張する言説も見られ一貫していない（11）。大正中期 に入ると 1919（大正 8）～1923（大正 10）年刊行の文献に [二階配 置]に関する言説が継続して確認できる（i1）。そののち一時期掲載 頻度を減少させるものの、再び1933（昭和 8) 年以降に継続して確認 できる（i2）。昭和期以降になると［居間兼用］と［応接間・書斎兼 用］といった客間との［兼用］が継続的に確認できるようになる（j・ $\mathrm{k} 1$ )。総じて大正 $8 \sim 12$ 年頃の期間に [二階配置]が集中的に見られ、 昭和期以降には［二階配置］と［兼用］の双方に分散する。

以上を居間の動向と照らしてみると、居間の［家事監督］[南面配 置）と客間の [二階配置］が継続的に記述され始めた時期が重なる (b1, f1, i1。【I】で示寸線)。つまり居間の機能が公的な性格を帯び はじめ南面配置の言説が定着したことより、それまでは部屋の方位 の从が客間の配置方法の論拠であったものから、二階への配置を言 説として導き出す契機になったと解釈することができる。

\section{3 寝室の二階配置に関する動向}

寝室の配置方法についても同様に整理した結果、客間と同じく [二

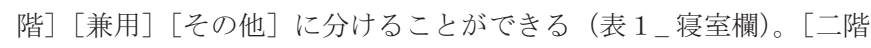
配置]の記述は、1915 年 (大正 4) 年の『理想の住宅』(No.9) から 1926 (大正 15) 年の文献まで継続的に確認できるが、多くは[洋風住宅・ 洋室］の場合に限定して推奨されたものであって、反対に［和風住宅・ 和室］の場合は一階配置を推奨する記述が続けて見られる $(\mathrm{m} ・ \mathrm{n} 1)$ 。 こうした傾向に変化がみられるのは大正後期から昭和期初頭にかけ てであり、昭和期に入ると $[$ 和風住宅・和室 $]$ へ言及自体が急減し (m1 以降)、[洋風住宅・洋風］への言及についても、断続的な頻度に減 少する (n2)。こうした減少傾向と反対に大正後期頃から住宅の［和 洋区別無）〈寝室の二階配置を推奨するような言説が徐々に確認で きるようになる（o1）。一方［兼用］については、1907（明治 40）年 から 1921 （大正 10）年にかけて [居間兼用] が継続的に確認できる が（p1）、これも大正後期以降にやや出現頻度が低下寸る (p2)。

以上を居間の動向に照らしてみると、大正期後半に、居間の[家 族共用］［椅子座］［住宅の中央部］が継続的に記述され始めた時期 と、寝室の［居間兼用］の出現頻度の低下と［和洋区別無］く二 階配置が推奨された始めた時期が、概ね重なるように捉えられる。 (c1, ei, g1, o1, p1，【II】で示寸線)。つまり「居間は普通の場合主人 と夫人の寝室をも兼致るもの」 ${ }^{40)}$ とされていた従来的な一階・居間 での就寝行為が居間のいわゆる「リビングルーム」化によって希薄 にさせたことがその誘因の一つとなり ${ }^{41}$ 、相対的に二階配置の言説 が増加したものと解勫することができる (n2,o1)。

\section{4. 客間ならびに寝室における二階配置の言説化について}

これまで客間、寝室の二階配置に関する言説の出現頻度について 居間の機能・配置方法の変化と対応しながら検討した。続いて客間、 寝室の二階配置の言説化がどのような背景をもとに形成されたかを 記述内容から検討する。なお、客間、寝室それぞれの言説のなかで 居間と関係する記述内容も抽出し、あわせて検討を行う（表 2 、表 3 ）。 
表 1 対象文献リストおよび居間・客間・寝室の記述動向

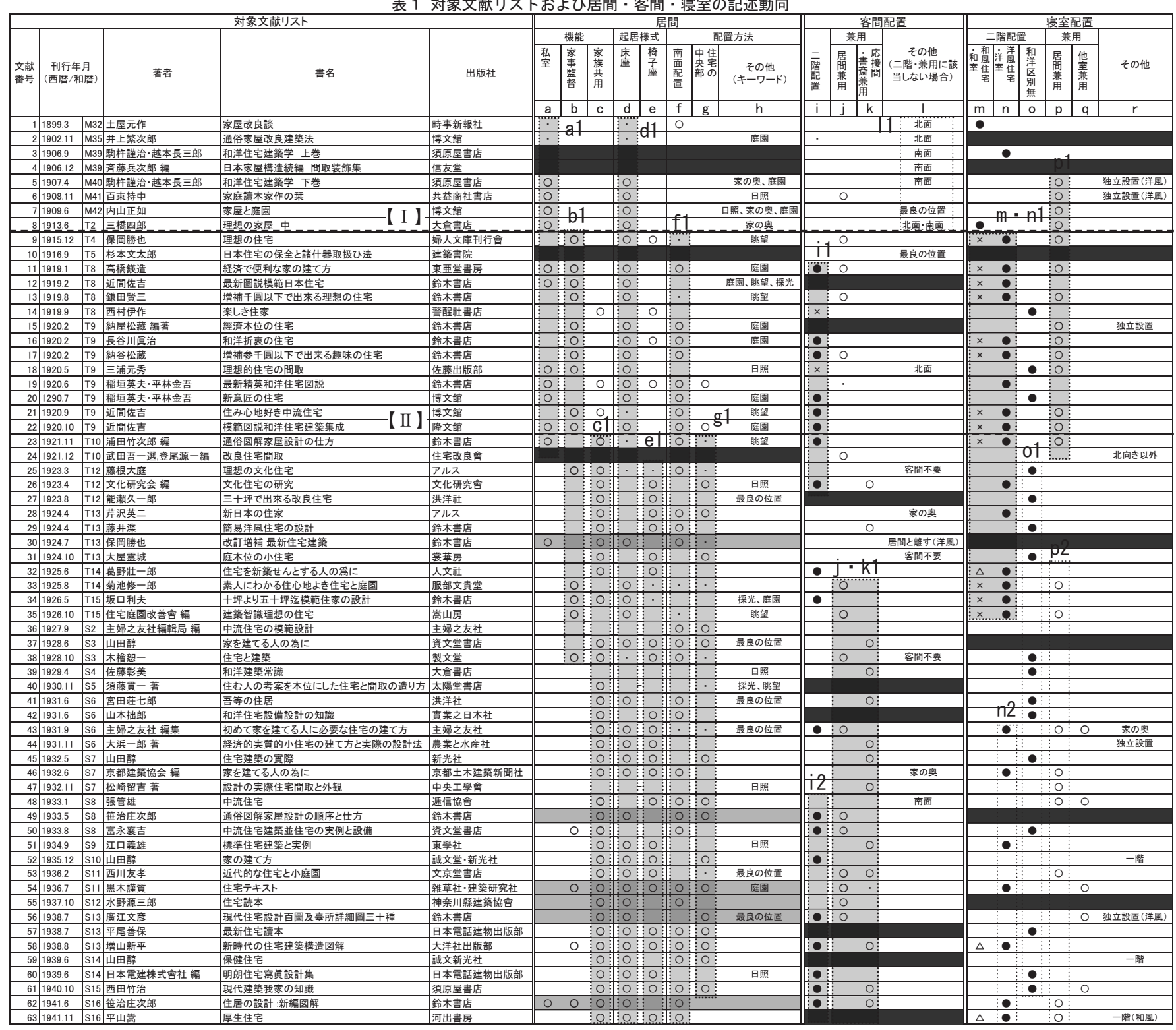

範例 ○:該当記述あり : : 直接的言及は無いが文章内容、挿図ならびに他の項目解説から推察できるもの— - : 記述内容等からは判断できないもの

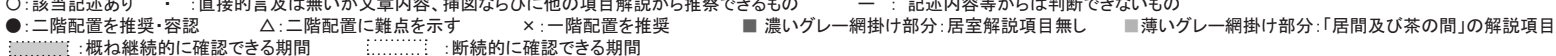

表 2 客間の二階配置に関する記述の動向

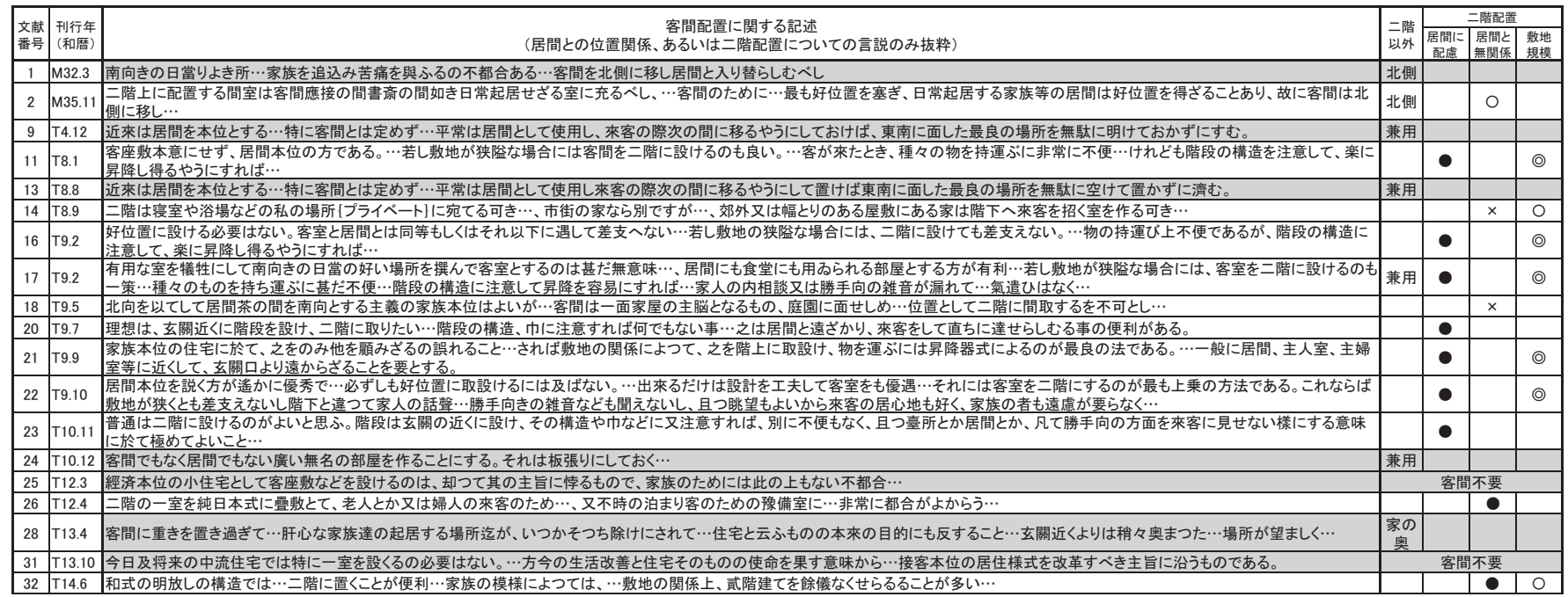


表 2 のつづき

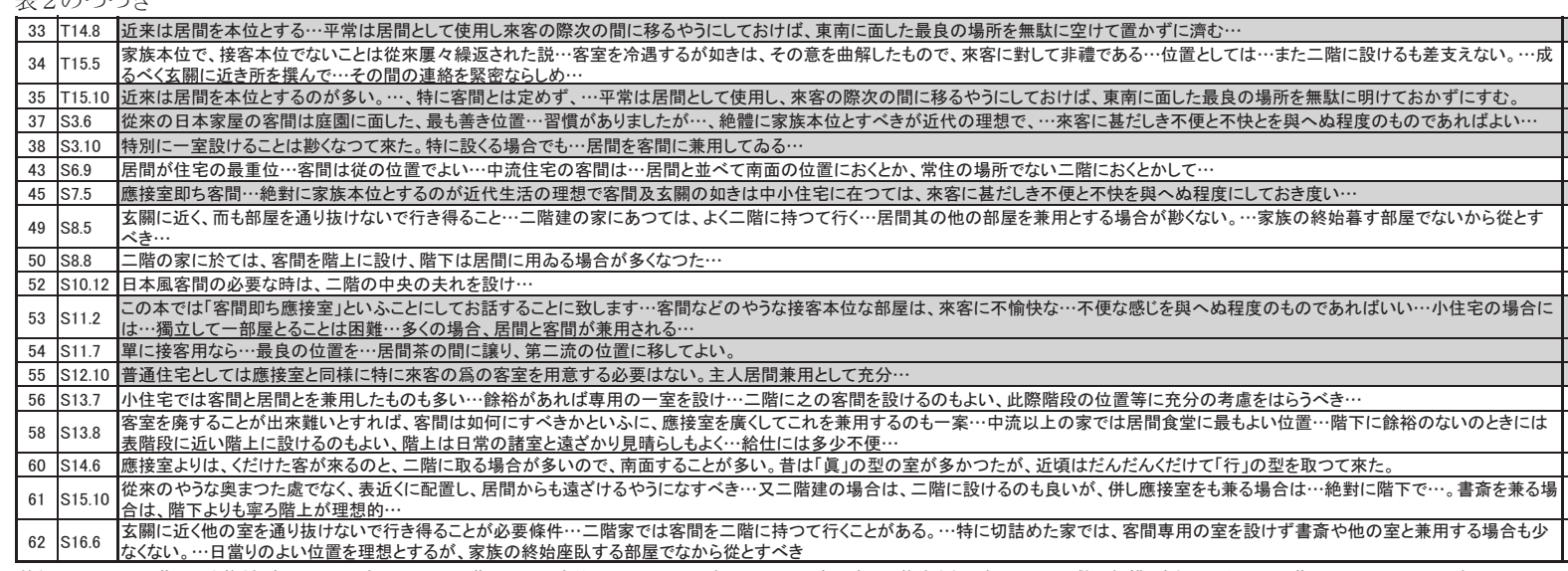

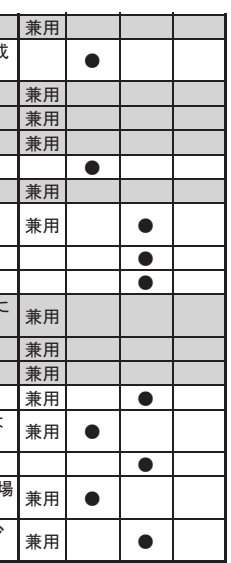

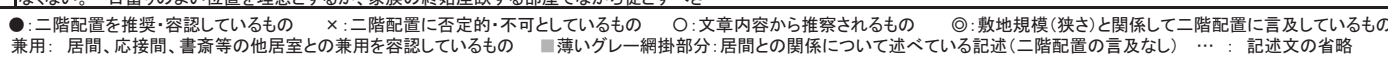

\section{表 3 寝室の二階配置に関する記述の動向}

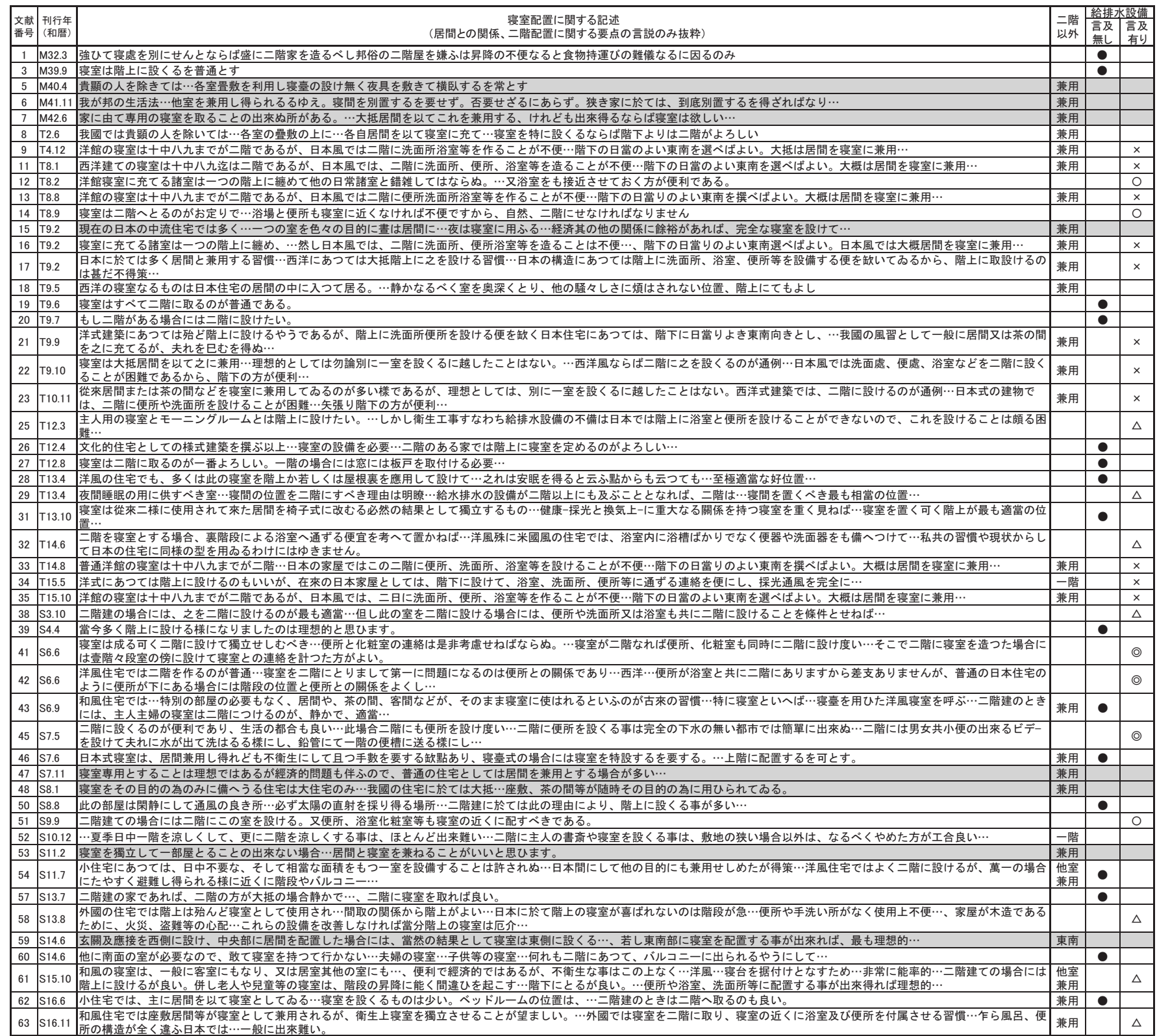

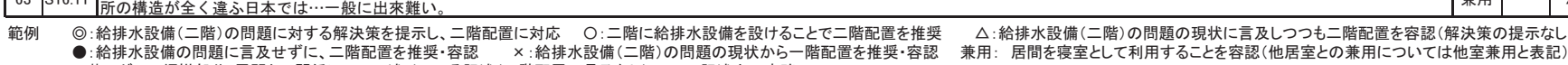

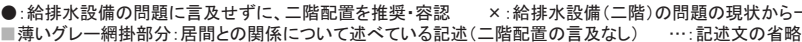




\section{1 客間の二階配置の言説化}

客間の二階配置に関する記述について、居間に対する配慮の有無 を判別しながら、その記述内容を整理した（表 2 ）。最初の 1899 （明 治 32）年『家屋改良談』(No. 1) および1902（明治 35）年『通俗家 屋改良建築法』（No 2 ）の 2 つの客間配置の記述に既に居間への配 慮が読み取られる。それらは「客間を北側に移し居間と入り替らし むべし」 ${ }^{42)} や 、 「 日$ 常起居する家族等の居間は好位置を得ざることあ り、故に客間は北側に移し」 $\left.{ }^{43}\right)$ という記述内容であり、客間を北側 に配置するといった対処法であった。このうち『通俗家屋改良建築法』 には客間の二階配置にも触れられているものの、居間への配慮から 二階配置が導かれてはいない。そして大正期の初頭を過ぎると次の ような記述が現れるようになる。

普通は家の最上の部分を客座敷と定めるが近來は居間を本位とする人も 往々ある。… (中略)、平常は居間として使用し、來客の際次の間に移るや うにしておけば、東南に面した最良の場所を無駄に明けておかずにすむ。 （保岡勝也『理想の住宅』婦人文庫刊行會, T4.12（No9））

「居間を本位」、寸なわち家族本位 ${ }^{44)}$ の方針が客間配置の記述のなか に明確に示され、客間の配置方法に居間を配慮することを前提とす る構図が形成される。ただしこの言説では「平常は居間として使用し、 來客の際次の間に移る」という続き間座敷を活用した居間との兼用 案であり、居間の南面化の問題も併せて答えようとしていて、まだ 二階配置の考えは導かれていない。そして 1919 (大正 8) 年の以下の 記述になると居間との兼用案とともに二階配置の言説が現れる。

平常は居間として使用し、來客の際次の間に移るやうにして置けば東南に 面した最良の場所を無䭾に明けて置かずに済む。…(中略)、若し敷地が狭 险な場合には客間を二階に設けるのも良い。人に依つては、客座敷を二階 に設けたならば、客が來たとき、種々の物を持運ぶに非常に不便であらう 云ふ人もあるだらうが、成程階下に比すれば階上は都合が悪いけれども階 段の構造を注意して、楽に昇降し得るやうにすれば左程不便を感ずること は無い筈である。

（高橋鍈造『経済で便利な家の建て方』東亜堂書房,T8.1（No.11））

こうした居間の配置を優先しつつ客間の二階配置案に結びつけるよ うな記述は上記を含め大正 $8 \sim 10$ 年の文献に集中している（表 2 [居間に配慮］の項目に相当)。また、これらの言説には、「敷地規模」 と関係づけながら記述されていることにも注目することができる。 先の記述とは別の一例を次に記す。

客室の位置に就ては…（中略）居間本位を説く方が遙かに優秀で、又合理 的…（中略）客室を二階にするのが最も上乗の方法である。これならば敷 地が狭くとも差支えないし…（中略）若し之を階下に設くるとすれば、一 軒の家で室を全部南向にすると云ふことは不可能で、それには中庭を取れ ば幾分其の目的を達することが出來るが、その代り面積が廣くなるので、 不経済の場所も出て來ることを覚悟しなければならぬ。

（近間佐吉『模範図説和洋住宅建築集成』鈴木書店, T9.10（№. 22））

このように居間本位を掲げつつ、客間の二階配置を推奨することに
対して、「これならば敷地が狭くとも差支えない」と見解している。 その後に客間を一階配置することを想定した場合の記述が続き、「全 部南向にすると云ふことは不可能」「中庭を取れば幾分其の目的を 達することが出來るが、その代り面積が廣くなるので、不経済」と して一階平面だけでは居間と客間の両方を南面配置させることが困 難な敷地規模を前提におきつつ、二階配置を推奨している。こうし た「若し敷地が狭险な場合には」、敷地の関係によって」などといっ た同様の記述が対象期間を通しても大正 $8 ， 9$ 年頃の文献に集中して いる（表 2 _@の記述に相当）。ところがその後の文献の言説を追う と、こうした記述は継続せず、「二階家では客間を二階に持つて行く ことがある」 ${ }^{45)}$ など、客間を二階におくことの意味に触れないまま 紹介されるなど、やや形式的な扱われ方も現れる（表 2 - [居間と無 関係］の項目に相当）。これは昭和期以降に［居間兼用］や［書斎・ 応接間兼用の兼用案が増えたことと関係すると見られ、（表 $1_{-} j$ · k1）、一つの独立した居室として客間を確保すること自体にやや消極 的な見方が出始め ${ }^{46)}$ 、二階配置を積極的に推奨する論拠が希薄化し たことが要因に挙げられる。

ちなみに、客間を二階に設けること自体については、実際は大正

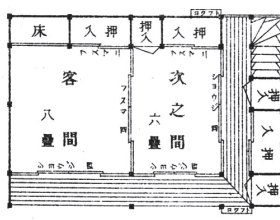

面平上階

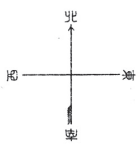

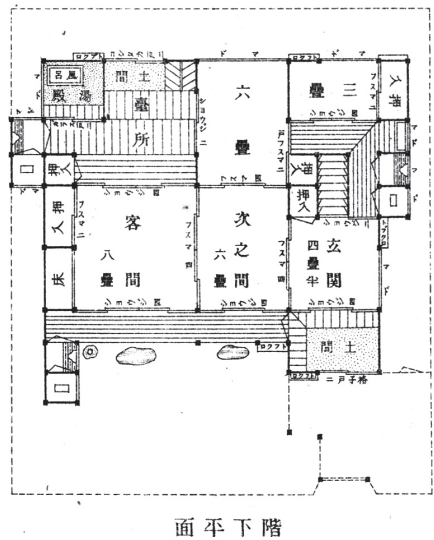

面本下階
図 1 一階・二階平面の両方に客間の室名表記をもつ図案 (金子清吉 :『日本住宅建築図案百種』第六十四圖, 1913.09 (大正 2 年 9 月))

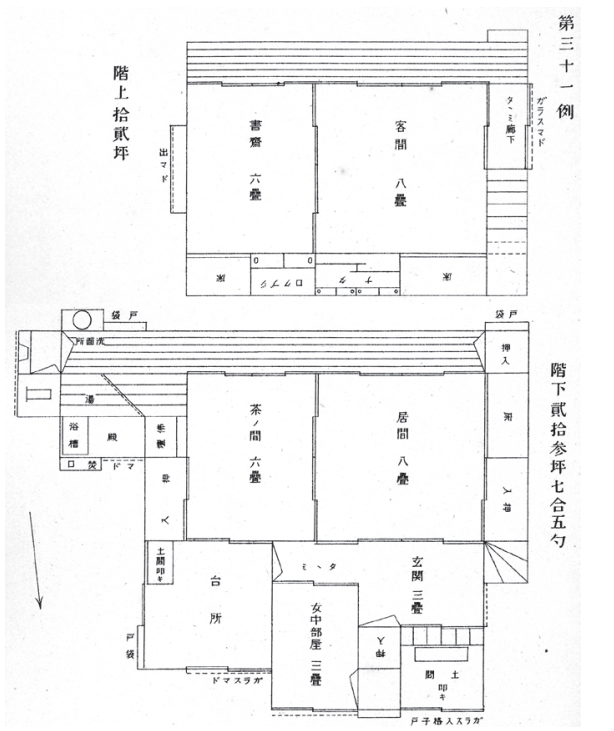

図 2 二階座敷を客間、一階座敷を居間と表記している図案 (納屋松蔵:『増補参千圓以下で出來る趣味の住宅』第三十一圖, 1920.02(大 正 9 年 2 月)）「玄關は北に面して南をあけ、西は直に隣家に接し、東は若 干の空地があつて採光に充分である…（中略）階段は玄關より直接なるが よく、又階段の配置も此の家族には適當で、殊に多數の來客のある場合に 便利である。」 
期以前には既に一般化していたとみられる ${ }^{47)}$ 。ただしそれは図 $1^{48)}$ のような、一階と二階両方に座敷を配し、接客利用の融通を利かせ ることを重視する間取りの方針 ${ }^{49)}$ が支配的であったとみられる。こ のことを踏まえながら大正中期の動向を改めて見ると、居間の南面 化をはじめとする家族本位の主張を間取り方法に取り入れるため、 一階の座敷を居間に譲り、残る二階座敷を客間にすることで対応し ようとする動きから、客間の二階配置が言説化したとも捉えられる。 寸なわち「2 階座敷説」 ${ }^{50)}$ はさほど敷地に余裕のない都市住宅的な 二階建て住宅の間取りを想定し、当時の実態に即しつつ居間と客間 の共存策から導かれたものであったと推察できる(図 2)。

\section{2 寝室の二階配置の言説化}

寝室の二階配置に関する記述については、二階配置の要点として 給排水設備の二階化に対する言及の有無により、その記述のされか たに大きな差異がみられたため、それらをもとに整理した（表 3 ）。 給排水設備の二階化に対する言及は大正期の文献から次のように記 述され、それ以降継続的に確認される。

洋館の寝室は十中八九までが二階であるが、日本風では二階に便所洗面所 浴室等を作ることが不便であるから、階下の日當りのよい東南を撰べばよ い。大概は居間を寝室に兼用寸る。

(鎌田賢三『増補千圓以下で出來る理想の住宅』鈴木書店, T8. 8(No. 13))

このように、洋館における寝室配置を「十中八九までが二階」と例 に挙げながら、日本風の住宅では「二階に洗面所浴室等をつくるこ とが不便」として一階の日当たりの良い東南に面して設置すること を示唆している。ただしそこには南面配置化した居間と位置が重な ることも見越して、「居間を寝室に兼用」寸ることを追認するかたち がとられている。洋風住宅と和風住宅の住宅設備に対する基本的な 捉え方の違いを対比的に用いながら、寝室の設置階の対応方法を区 別するような論述方法は、これ以降の文献にも連続して確認できる が、その文体がどれも酷似している。恐らく過去の著書からの引用 が繰り返されている可能性が高いとみられるが、そうであったとし ても、二階に水回り設備をおくのが困難な状況は、当時の建築家ら にとってそれほど二階を計画するうえで共通する懸念事項であった とも考えられる。それは寝室以外の記述内容である「給水と排水」 という項目における言説からもその様子が窺える。

建物の排水状態をみると、一般に甚だ不潔不完全であつて、何人も今日 の有様で満足するものはありますまい。かく給水に比して排水が甚しく幼 稚であるのは何故でありませうか。その主なる原因は都市下水施設の未完 成すなわち都市に污水を派除する設備がないからであります。今後都市に 下水の設備が完備しますと $\cdots$ (中略)、便所の粪尿も水洗式の便器と、之に 連なる污水管との設備によつて、全然密封のまま悪臭や有害な瓦斯の発散 を防止しつつ、二階からでも、三階からでも安全に市設の暗渠に排除し得 られるのであります。

（藤井渫『簡易洋風住宅の設計』鈴木書店, T13.4（No. 29））

ここでも国内における都市下水整備が及んでいない状況を憂慮して おり、二階以上の階の計画をより自由なものにするためには便所の 水洗化が必要不可欠な技術的要素と捉えられていた。また他の文献

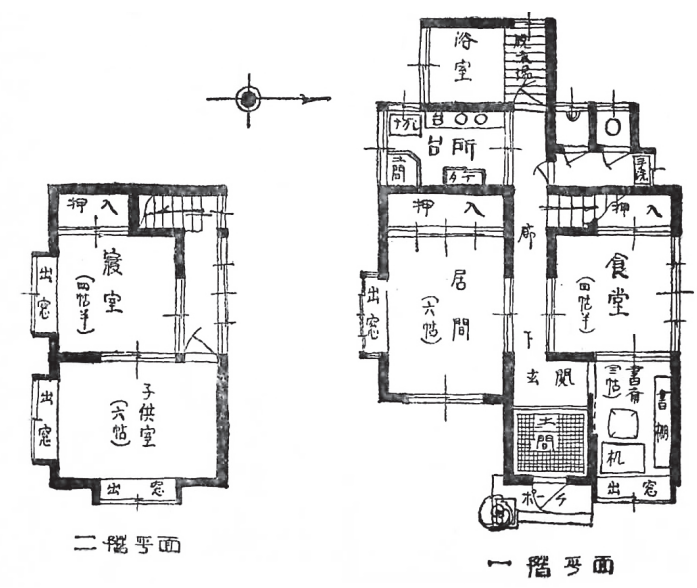

図 3 玄関から奥の位置に便所と階段を配置した図案

(宮田荘一郎：『吾等の住居』第十二圖 , 1931.06 (昭和 6 年 6 月) ) 玄関より奥まった位置に階段を配置し、その付近に便所を配置すること で二階寝室からの便所までの動線と玄関からの視線に配慮が見られる。

では、「位置は出來得る限り最も閑静なる場所を撰び便所、手水場、 浴室等に近く（洋室の時に特に然り）配置し…」 ${ }^{511}$ の記述に見られ るように、寝室と水回り空間を一体的に捉えるような見方、つまり 西洋住宅の就寝空間のイメージを背景 ${ }^{52)}$ にしながら説明しているこ とも、寝室の二階配置の言説化を鈍らせる要因であったとみること が出来る。ところが、昭和期の初頭を過ぎると、それまでの記述の しかたに対してやや变化をつけたような言説が現れるようになる。 それは以下のような記述であり、

洋風住宅では二階を作るのが普通であり…(中略)、寝室を二階にとりまし て第一に問題になるのは便所との關係であります。西洋人は從來寝室を便 器を備へましたし、また便所が浴室と共に二階にありますから差支ありま せんが、普通の日本住宅のように便所が下にある場合には階段の位置と便 所との關係をよくしまして $\cdots$

(山本拙郎『和洋住宅設備設計の知識』實業之日本社, S6.6（No. 42)）

二階に便所を設くる事は完全の下水の無い都市では簡單に出來ぬのであり ますから、私は二階には男女共小便の出來るビデーを設けて夫れに水が出て 洗はるる樣にし、鉛管にて一階の便槽に送る樣にして居ります。

(山田醇『住宅建築の実際』新光社, S7.5 (No. 45))

というように、一階便所と階段の位置関係に配慮すること（図 3 )、 または簡易的な便所設備を二階に置くことで寝室の二階配置に結び つけようとする方針が読み取れる。前述した給排水設備の二階化そ のものを見るのではなく、現実的な工夫が提示されているといえよ う。こうした言説の該当数は昭和期の文献全体から見ると限られて いるが（3/28 件、表 3 の○が付く部分の記述）、「居間を寝室に兼 用する」言説が、なかば引用的に繰り返されて用いられていた時期 (表 3 _給排水設備の $\times$ に相当する記述）と比較すれば、寝室の二階配置 に対する言説が内容的に進展したと捉えられる。全般的には大正後 期から、[和洋区別無］〈寝室の二階配置を推奨するような言説が増 加しており、そのなかでこうした言説が含まれていることから（表 1_o1 部分の No41, 42, 45 が該当)、寝室の二階利用の模索が進み始め た段階とみることができる。 


\section{5. 結論}

本稿は、明治後期から昭和初期までの住宅関係単行本に掲載され た客間、寝室の居室配置方法に関する言説を対象に、その二階居室 配置に対する動向およびその背景を一階における居間の機能とその 配置方法の変化と照らし合わせつつ読み解くことで、近代都市独立 住宅の二階建てに対する理念形成を明らかにした。以上の結果を居 間の動向から捉え直すと以下のような変遷をたどることができる。

明治期は従来の私室としての居間機能に大きな変化は見られず、 客間や寝室の配置方法への影響は見られなかった。大正期に入り、 居間が公的な意味を持ちはじめることで南面配置が重視され、さら に「家族本位」という考えが定着し客間の間取り方法にまで居間一 の配慮が明確に示されたことにより、大正中期において客間の二階 配置が言説化した。そして大正後期になると居間の「リビングルーム」 化が言説に現れ、家族共用の団らんの場としての洋室（椅子座）の 居間空間も想定されるようになった。それは従来の居間に備わって いた就寝機能を分離させる契機となり、それに影響するかたちで大 正後期〜昭和期初頭の期間において寝室の二階配置が言説化した。

そして客間の二階配置は居間と客間の間取りの共存策として言説 化したのに対し、寝室の二階配置は就寝空間の独立を目的とする一 貫的な取り組みのなかで言説化したものであり、技術的な問題に応 じる姿勢も一部で確認できた。つまり二階の寝室化の志向性が認め られ、わが国現代住宅の二階のあり方が戦前から構築されようとし ていたことが指摘される。

こうした一連の言説から読み取られるのは、様々な生活行為の包 含が許容されていた在来的な部屋概念から、居間の役割を明確に規 定させていく建築家らの試みであって、その行程から間取りの機能 分化が生じている。そこに二階に間取りの余地を見出そうとする姿 勢が読み取れるのであり、これが二階建て住宅に対する理念形成の 背景であると考えられる。こうした建築家らによる間取り方法の言 説化の蓄積は、戦後から現代の独立住宅に対寸る計画的思考の基盤 となった可能性は十分に考えられ、二階建てもそのなかに含まれて いるのである。

\section{謝辞}

本研究を進めるにあたり、平成 27 年度佐賀大学大学院工学系研究科 若手研究者支援経費の助成を受けた。記して感謝したい。

注

1）本稿で扱う居室とは、住宅において継続的に使用される室の一構成要素とし ての意味で用いるものとする。なお「居室」は個人専用の部屋の意味として 用いられる場合もあるが、意味の混同を避けるため個人専用の部屋は「私室」 として区別することにする。

2）上流階層の住宅建築における二階建ては、例えば臨春閣や拾翠亭といった現 存遺構が明治期以前のものとして確認できる。いっぽう商家における二階建 ては規制の対象であったものの、京阪地域では 18 世紀後半から住宅の背後 の部分で二階座敷が発達し、江戸では 18 世紀から本二階の形式が多かった といわれている。ただし二階を一階と同じように居室として利用することは、 裕福な階層に限定されると見られる。江戸期の町家における二階の発達は鈴 木嘉吉『日本の民家 6 町家』(学習研究社, 1980) に詳しい。

3）日本の住宅における二階建ての増加の動向は、戦前期までの住宅関連の統計 資料が乏しいため、具体的な数字として表すことは困難であるが、現存遺構 や史料から二階の存在について度々報告されている。また、江面嗣人：『日 本の美術 449 近代の住宅建築』(至文堂, pp. 64-65, 2003) では、「近代の住 宅の二階化」について、また大岡敏昭 :『日本の住まいその源流を探る』(相 模書房,p. 73, 2008.3) では「住まいの二階化」について述べられており、こ うした記述からも近代の住宅における二階化の浸透の様子が窺える。

4) 『日本の美術 449 近代の住宅建築』(前掲書（注 3)）では「都市人口の増加 に伴う居住面積の不足」に加えて、「間取りの機能分化」を近代における二 階化の要因にあげている。

5）本稿では「居間」そのものの機能変化を取り扱うため、対象文献に掲載され ている間取り方法に関する解説において「居間」と記載されているもの全て を対象とした。なお一部の文献にて「居間及び茶の間」というような、茶の 間と一体的に解説される場合があり、これも対象に含めた（その場合は表 1 居間欄にて、薄いグレー色で網掛け表記して区別した)。

6) 平井聖：「近代都市住宅に於ける茶の間」(学苑 No. 803, pp. 1-21, 2007.9) に よれば、近代において「茶の間」の概念変化がみられ、南面する座敷と並び、 間取りの中心的な位置を占めるようになったことが指摘されている。「茶の間」 は「居間」に隣接することが多く、機能も互いに共通寸る部分がみられるため、 この「茶の間」を含めた動向を分析する必要性はある。しかし間取りの機能 分化と二階の居室配置という観点では、「居間」の動きの方に特徴的な変化 が見られため、本稿の分析では「居間」のみに対象を絞った。

7）青木正夫・岡俊江・鈴木義弘: 『住まい学体系 102 中廊下の住宅 明治大正 昭和の暮らしを間取りに読む』（住まいの図書出版局, pp. 172-175, 2009.3) に よれば元来、私室の意味をもっていた「居間」は生活改善同盟会によって「団 らん空間としての居間」として概念規定されたが、それは「建築家だけに通 用する概念」にとどまるものであったとし、戦後高度成長期にようやくそう した意味内容への移行がみられると述べている。なお一般的な解釈として、 戦前までは「茶の間」が団らん空間の役割をもっていたと述べている。

8）本稿で取り扱う「客間」とは、接客利用を一義的に考えた部屋を指し、客間、 客室、(床の間付きの) 座敷の室名表記が用いられているものを取り扱う。

9）本稿で取り扱う「寝室」とは、家族個人の就寝利用を一義的に考えた部屋を 指し、寝室、寝所、寝間の室名表記が用いられているものを取り扱う。

10）江面嗣人：「明治・大正期における佃島の住居の類型と変遷」日本建築学会 計画計論文報告 No. 396, pp. 100-113, 1989.2

11）百田直美・松岡高弘：「柳川の住宅に於ける 2 階の造りについて-柳 川の近代の住宅に関する研究 その 11-」日本建築学会九州支部報告 No. 55 , pp. 609-612, 2016.3

12）吉田高子：「池田新市街（室町）分譲住宅地と住宅について-近代中流階 級住宅の成立に関する研究一」近畿大学理工学部研究報告 No. 25, 1989.9, pp. 271-280.

13）古俣和将・内田青蔵: 『階段』からみたわが国戦前期の住宅の変遷に関する 一考察一戦前期に刊行された住宅関連書籍を主史料として一」日本建築学会 学術講演梗概集（建築歴史・意匠）, pp. 449-450, 2014.9

14）立川智浩・丹羽和彦：「わが国近代における『二階』の展開，日本建築学会 学術講演梗概集（建築歷史・意匠）, pp. 589-560, 2003.9

15）木村徳国：「日本近代都市独立住宅様式の成立と展開に関する研究」，北海道 大学工学部研究報告 No. $18 \sim 21,1958 \sim 1959$

16）青木正夫 :「明治以降の住様式の変化・発展に関する一考察」（住宅建築研究 所報 NNo.12,1986)により木村の学説(注15)について一部見直しがはかられた。 さらには内田青蔵：『日本の近代住宅』（鹿島出版会,1993）により通史的整 理が施されるなど、近代的な住宅平面の成立過程に関する史的研究は充実し たものとなっている。

17）宮崎信行・青木正夫・友清貴和: 「大正初期の我が国における家族本位計画 論の成立について一衛生面からみた住宅の平面計画に関する史的研究 その 4-」（日本建築学会計画系論文集 No. 496, pp. 65-72, 1997.6）において、山崎 孝吉による座敷の二階配置の言説を引用し（光岡義一編『住宅建築』世界建 築社 1916. に収録)、これを家族居室の南面配置をめぐる計画論上の $1 つ 0$ 試みと紹介し「2 階座敷説」と定義している。しかし「町家の例にみられる ように、在来住宅の平面計画内容」が含まれ、「在来住宅の立場を脱してい ない」家族本位計画論の成立途上の考えであったという位置づけがなされて いる。なお「2 階座敷説」の出現時期やその具体的内容は分析されていない。

18）前揭書 (注 16)

19）前掲書（注 16），(注 17）, 双方とも住宅平面計画理論の成立過程を主題と する研究であり、二階建てを分析した研究ではない。そのため居室の二階配 置方法については一部の事例紹介にとどまっている。

20）主に、㴊上貴由樹・内田青蔵：「わが国近代の住宅における『寝室』の二階配 置について - 明治後期から昭和初期に刊行された住宅関連書籍の記述を用い て -」日本建築学会大会学術講演梗概集 (建築歴史・意匠), pp. 877-878, 2016.8、 㴊上貴由樹：「階段位置・二階動線からみた近代和風邸宅の二階平面の変 化」日本建築学会九州支部研究報告 No. 55, pp. 613-616, 2016.3. なお本論文 
は 2016 年日本建築学会大会学術講演での発表内容をもとに大幅な加筆・修 正を行ったものである。

21）明治期から昭和戦前期までにおける住宅平面理論に対する議論には、建築設 計を専門とする建築家だけでなく、建築技師、学識経験者、教育者、著述家 等といった建築家以外の意見が多分に含まれている。それは当時、建築家と いう職能が未だ確立途上の段階であったことにも関係するからであろうが、 世間一般の関心事でもあった在来住宅問題の改善という意味において、様々 な見識の角度から住宅に対寸る意見が出されたことは重要であったと考えら れる。そのため本稿では「建築家ら」の言説として包括的に扱うこととした。

22）住宅関係単行本を史料とした分析方法とは別に、建築専門誌を史料とする方 法が考えられるが、専門誌といら情報媒体の性質上、住宅建築に関するある 特定のテーマに絞られて記述される傾向にある。本文にも述べているように、 「二階、「二階建て」は主階である一階部分への言及に比べると副次的な内 容であることが考えられるため、雑誌という限られた紙面上に住宅理論とし て言及されるのは限定的であると考えられる。その意味では住宅関係単行本 の方が、個々の建築家らが住宅に対する考えを完結して述べることが出来る 環境にあると考えられ、居室の二階配置に関寸る言説を対象期間においてま んべんなく収集できると判断した。

23）「中流」という社会的階層範囲について、木村は「中流住宅の概念と敷地確 立は切り離し得ないもの…(中略）住宅規模にかかわらず…」（前掲書（注 15)）と述へ、敷地の確立されている住宅を「中流」の条件にあげている。す なわち確立した敷地に居を構え、家主自ら住宅間取りを思案する行為が可能 な人々を都市中流層として捉えることができ、こうした階層の台頭が通俗向 けの住宅関係単行本の需要を喚起させたとも考えられる。一方で住宅規模か ら「中流」を捉える方法も考えられるが、本稿では住宅図面を用いた分析を 行わないことから、以上のような広義的な意味から捉えるものとする。

24）近代における住宅関連書籍の刊行増加傾向については、田中友加里・藤木竜 也 : 「1950 年代までの住宅関係書籍にみる刊行推移とその分類について 住 宅関係文献にみる住まいの様相に関寸る実証的研究」（日本建築学会中国支 部研究報告集 No. 33, 2010.3）に詳しい。これによれば 1920 （大正 9）年から 1939 （昭和 14）年の期間に大きく刊行数を増加させていることが報告されて おり、それは本研究の対象とする史料の刊行年の構成と概致一致する（表 1 )。

25）例えば、文献番号 34 の坂口利夫 :『十坪上り五十坪迄模範住家の設計』（鈴 木書店, 1926.5）の目次の見出しを例にすると、「計畫から施工まで」、「各室 の設備と建具」「室内装飾の基調」「家庭電化の常識」「美しき庭園と門牆」、 「構造並に材料の見方」「模範住家間取圖集（附録図）」といったように内容 が多岐にわたる。そして序文には「本書の期する所の要は、一に住宅建築の 常識を訓鍊して」と記されている。このように当時刊行された住宅関係単行 本の多くは、建築の素人や初学者向けに対する手引き書としての性格を帯び ていた。なお祐成保志:『〈住宅〉の社会学』(新翟社, 2008.10)に上れば、「住 宅手引書」という出版ジャンルの確立」として、1920 年前後にこうした種類 の書籍が多数刊行されていたことについて言及している。

26） 2016 年 4 月 10 日時点の「国立国会図書館サ一チ」の検索結果による。

27）日本十進分類法 (NDC) 分類記号：520

28) 日本十進分類法 (NDC) 分類記号 : 527

29）表 1 の項目にあげている他に、居間の解説には「食事」や「就寝」といった 生活行為に関寸る記述が含まれる。これらは居間の代表的な機能であるが、 「食事」はどちらかといえば居間に隣接する台所や茶の間の方に関係すると みられ、また「就寝」については「寝室」の二階配置の言説から居間との兼 用について述い゙られ、そこで相互の関係について確認できるため、居間の分 析項目から割愛した。

30）井上繁次郎：『通俗家屋改良建築法』博文館, p. 18, 1902.11

31）駒杵謹治・越本長三郎 :『和洋住宅建築学 下巻』須原屋書店, p. 216, 1907.4

32）保岡勝也 :『理想の住宅』婦人文庫刊行會, pp. 159-160, 1915.12

33）西村伊作 :『楽しき住家』警醒社書房, pp. 37-38, 1919.9

34）本稿で扱う床座は、基本的に畳敷きの床を想定している。ただし床座であっ ても板敷きの場合は、椅子や卓子などの洋風家具が置くことも可能となり、 さらには畳敷きであってもその上に絨毯を敷いて洋風家具を配置すれば椅子 座となる。したがって言説や解説図からこのような内容が読み取られる場合 については、[床座］[椅子座］両方ともに該当するものとした。

35）土屋元作：『家屋改良談』時事新報社, p. 109, 1899.3

36）内山正如 :『家屋と庭園』博文館, p. 88, 1909.6

37）宮崎信行・青木正夫 : 「明治 30,40 年代の我が国における家族居室の南面配 置をめぐる計画論上の試みについて-衛生面からみた住宅の平面計画に関す る史的研究その 3-」(日本建築学会計画系論文集 No. 483, pp. 111-120, 1996.5) によれば、家族居室の南面配置の試みは明治 30,40 年代にはすでに、計画論
上の試みとして一層具体的に記述され、家族本位の平面計画観は形成されて いたと述べられており、理論として既に確立していたと見られる。本稿で扱 う建築家らの個々の言説に継続的に現れるのは、大正期以降のことであるこ とであるため時期的な差異がみられる。恐らくこうした理論的な考え方が建 築家らに咀嚼・浸透し、それが単行本の間取り方法の解説に言説として扱わ れるまでに一定の時間を要したことが要因に考えられる。

38）「生活改良の立場」から家族本位に言及していることから、大正 10 年 9 月に 生活改善同盟会が示した提言「住宅の間取及び設備の改善」による影響が考 えられる (「建築雑誌」No.419, 日本建築学会, 1921.9 に掲載)。「共用室と専 用室との別を設くること。… (中略)、先づ共用室を椅子式に改めよ…上解 説され、共用室としての居間、寸なわち「リビングルーム」としての居間空 間が念頭に置かれていた。生活改善同盟会を主体と寸る住宅改良の試みは、 建築界を超えたムーブメントとして拡がりをもち、大正後期の建築家の住宅 思想に一定度の影響を与えたと考えられる。なお生活改善運動の動向につい ては内田青蔵：『日本の近代住宅』(注 16) に詳しい。

39）（注 7）と同心゙

40）三橋四郎：『理想の家屋 中』大倉書店, p. 22, 1913.6

41）青木の研究（前掲書（注 16）, p. 20）によれば「居間が椅子化したため必然 的に寝室は出された形で必要となった」と述べており、寝室の独立化が促さ れたと考えられる。

42）前掲書（注 35）pp. 108-109.

43）前掲書（注 30） p. 18.

44）宮崎らの研究（注 17）によれば、「家族本位」の言葉を用いて、接客用居室 に対する家族用居室の優位性を概念的に示したしたのは伊東忠太の「中流の 住宅は如何に設計寸べきか」が始まりであるとしている。(「婦人の友」主婦 之友社, pp. 24-31,1916.8 に収録)。それ以前の明治期においても、家族居室 を重視する考え方はあったが、明確な言葉によって概念規定されたことによ り、家族用の居室、とりわけ居間を重視する方針が形成されていった。

45）笹治庄次郎：『住居の設計 新編図解』p. 39, 1941.6.

46）例えば、西田竹治:『現代建築我家の知識』(須原屋書店, p. 75, 1940.10)で は、「中産階級では、客室として客のみに使用する獨立した室を設ける事は 經済がゆるさない。併し乍ら、來客のあつた場合等、客を通すべき整頓され た室がないやうな事であつては、實に困惑せざるを得ないやうな事もあるも のであるから、このやうな場合に、應接室兼客室と謂ふやうな、假令小さな 室でもあれば、赤面をせずにすむばかりでなく、非常に便利で、決して不經 済な事はない」のうに、室機能の兼用提案がみとめられる。その要因として、 木村（注 15）や西山卯三 (『日本の寸まいII』勁草書房, 1967.6)）が述べて いるような大正期から昭和期までの住宅提案における「中流」規模の下降が 関係していることがあげられる。つまり住宅のコンパクト化のなかで、客間 に対する書斎や応接室との兼用化が図られていったと考えられる。

47) 前掲書（注 10)、（注 11）、(注 12）明治期の独立住宅の二階には、接客利用 を想定した床の間付きの座敷が設けられていたといら報告がなされている。

48）図1の出典である金子清吉:『日本住宅建築図案百種』(建築書院, 1913.9) は、 図案とその解説文のみで構成された単行本であり、本稿が分析する居室配置 方法の言説が揭載されていない。そのため対象文献からは除外されているが、 本稿の定義する住宅関係単行本の性格を満たすものであり、明治後期〜大正 初頭の住宅提案の動向を見るためには有用な資料と判断できるため、この書 籍に掲載されている図版を用いた。

49）図 1 に示寸図案に併記されている解説文には「家族女中等六七人暮しに適寸、 南に門を有し、玄關より直接に二階客間及び下客間等に通ずるを得」として いることから、その住宅規模と居住人数からして通常は客間を家族居住の場 に充てられることが想定できる。それでも一階・二階の座敷を客間として位 置づけているのは、様々な接客場面にも対応可能とする接客時の融通性の重 視、寸なわち接客本位の考え方によるものと考えられる。

50) 前掲書 (注 17)

51）張管雄：『中流住宅』聥信協会, p. 128,1933.1.（）表示は原文ママ。

52）『高等建築学 14 巻』(常磐書房, pp. 131-132, 1933.6.) によると、「洋風住宅で は一般に二階に寝室を置き、これに浴室及び便所を附属させる習慣になつて いる (面白い事に、便所が二階だけにあつて一階にない様な家が西洋には實 に澤山あるらしいのである)。浴室（兼便所）は寝室 1 箇乃至 2 箇に一つづつ 附属する様な場合が多く、大きな住宅に於いて、浴室の數だけでも相當の數 になる。日本人が洋風生活を模倣して行つた場合、一般にこの様な方法まで 真似するや否やは多少興味ある問題であらう」と、ここでも西洋住宅の寝室 が水回りと一体的に計画されている様子に触れながら、日本の住宅に対して 西洋的な就寝空間をどこまで参照にするべきかを注視している。なお引用文 中の（）表示は原文ママ。 


\section{THE IDEA OF 2 STORY HOUSE FROM THE VIEW POINT OF CHANGE OF ROOMS FUNCTION AND ARRANGEMENT}

- The study on 2 story urban modern houses with discourse analysis of housing books published in prewar Japan -

\section{Takayuki FUCHIKAMI* and Seizo UCHIDA**}

\footnotetext{
* Assist. Prof., Graduate School of Science and Engineering, Saga Univ., M. Eng. (Researcher of Kanagawa Univ.)
}

** Prof., Dept. of Architecture, Kanagawa Univ., Dr. Eng.

This paper clarified the idea of 2 story house in modern Japan by using the discourse of 63 housing books published from the late Meiji to early Showa periods.

From the previous research it is thought that functional differentiation of floor plan promoted 2nd floor planning. Therefore, this research focused on the change of the "Ima" of the 1st floor at the time. "Ima" conventionally had the function as a private room, but also included various functions such as accompanying functions of sleeping and talking with visitors. Eventually, "Ima" shifted to a public room function western living room, we assumed that the establishment of functions of each other room was promoted and led to two stories planning. We analyzed how changes in the function of the "Ima" and that arrangement method affect the discourse of the arrangement method to 2 nd floor of the drawing rooms" and the bedrooms.

At the first, we confirmed that "Ima" changed its function as a public room in early Taisho era, and the discourse changed so that it was placed on the south side of the plan. In addition, around the time of the late of Taisho periods, the proposal of the "Ima" which became a Western-style room appeared. In this way the "Ima" got priority than the drawing rooms. So the discourses of the drawing rooms arranged on 2 nd floor were described in middle of Taisho period intensively. From the above, we considered that the idea appeared about the changing arrangement of the drawing rooms to the 2 nd floor to secure a space for the "Ima".

On the other hand, the discourses of bedroom's arrangement on 2nd floor did not formed smoothly than the drawing rooms it. It seems that the main factor was due to could not set up wet area on 2nd floor by municipal wastewater undeveloped at that time in Japan; It was difficult to put in bathroom around the bedroom like a western housing sleeping space. However, the discourses of arranging to the bedroom at 2 nd floor were also appeared in early Showa period. It seems that the major factor were the idea of the western style's the Ima (sitting on chairs, that means the living room) spread among the architects, on contrarily the idea of traditional sleeping style on tatami were reduced. Also, we confirmed that there were some discourses attempt to cope with towards the problem of municipal wastewater.

The discourses regarding the drawing room's arrangement on 2nd floor were caused from only a solution for the plan of the relationship between the Ima. In contrast, the discourses regarding the bedroom's arrangement on 2nd floor were caused from to the primary purpose to establish the sleeping space in the Japanese houses. It were consistent to arrange on 2nd floor.

We considered that the discourses related to the bedroom arrangement at early Showa period leading to aspects of the the 2 nd floor of the modern housing. In other words, It means that the planning idea of the 2 story houses had already begun to formed from this period. Also, from the housing books at the time, we could find that the attempt of the architects to clearly define the role of the living room changing from the traditional room concept (which allowed the inclusion of various functions). 